\title{
Herbage volume per animal: a tool for rotational grazing management
}

\author{
MICHEL DURU, HÉLÈNE DUCROCQ, AND LUC BOSSUET
}

Senior author is a research leader in Agronomy, INRA Agronomie, Chemin de Borde Rouge, BP27, 31326 Castanet Tolosan, France. At the time of this research, Ducrocq and Bossuet were respectively graduate sudent and extension agronomist, INRA SAD, Chemin de Borde Rouge, BP27, 31326 Castanet Tolosan, France.

\section{Abstract}

The objective of this study was to provide a tool for maintaining a high grazing efficiency. In a rotational grazing system, the residual sward height does not provide enough information in advance to make the recommendation. The grazing management of 4 commercial dairy farms which differed greatly in their stocking rate, was monitored over 3 spring seasons. Data were collected on the overall grazing area (sward height measurements, stocking rate, indoor feeding, nitrogen supply) and on 3 grazed fields (herbage mass, height, and nitrogen status). At the whole grazing area level, computed data were herbage volume per animal unit (HVAU).

We show that the HVAU depends on the residual herbage height. Both criteria decreased when stocking rate increased. The HVAU reflects, at the whole grazing season and area levels, how the system works on grazed field over grazing cycle. The HVAU has 2 advantages: (i) It gives rough estimation of the size of the whole grazing area to achieve a high grazing efficiency; (ii) it is a means to assess a posteriori the efficiency of the grazing system regarding the consistency between stocking rate and nitrogen supply management.

Key Words: herbage height, nitrogen, stocking rate, management, dairy farms

Despite its low production cost grazingland for feeding dairy cows and ewes is poorly utilized and is tending to give way to silage-making in many parts of Europe (Pflimlin 1995). We hypothesized that this trend is not merely the result of economic factors. In many areas in France, as fields were divided up, a rotational grazing system was imposed. In theory, this system allows greater flexibility than continuous stocking, because it is easy to add or to remove one or more grazed fields according to the herbage needs. In practice for convenience of management this implies (i) that the grazing system is designed, and feed budgets are established to define the area for grazing for different climatic assumptions; models in management research built from grass growth and intake models could be used (Bywater and Cacho 1994, Cacho et al. 1995) (ii) the need for a simple indicator to decide in real time to what extent the grazing area must be varied through the growing season (iii) a method to assess a posteriori the relevance of the grazing management beside output objectives.

Authors wish to thank the "'Chambre d'Agriculture de l'Aveyron" and the "Chambre Regionale d'Agriculture Midi-Pyrenés" which supported this research. Manuscript accepted 17 Oct. 1999.
Resume

L'objectif de cette étude est d'élaborer un outil permettant maintenir une efficience de pâturage élevée. Dans un pâturage tournant, la hauteur résiduelle ne permet pas à elle seule de fournir une information suffisamment à l'avance pour atteindre les recommandations. La gestion du pâturage dans quatre fermes laitières qui diffèrent par le chargement a été suivie durant trois printemps. Les données sont enregistrées à l'échelle de la sole pâturée (hauteur de l'herbe, chargement, distribution à l'étable, apport d'azote) et pour trois parcelles (masse et hauteur d'herbe, niveau de nutrition en azote de la prairie). Au niveau de la sole pâturée, le volume d'herbe par équivalent vache est calculé (HVAU).

Nous montrons que le HVAU dépend de la hauteur d'herbe résiduelle. Les deux variables diminuent quand le chargement augmente. Le HVAU reflète à l'échelle de la sole pâturée et de la saison de pâturage comment la prairie est gérée sur une parcelle et un cycle de pâturage. Le HVAU a cependant deux avantages: (i) il fournit une première estimation de la surface à pâturer pour atteindre une efficience de pâturage élevée; (ii) c'est un moyen d'estimer a posteriori l'efficience de pâturage en observant la cohérence entre le chargement et l'apport d'azote.

We discuss the 2 last items. The usual recommendations are based on residual sward height (Le Du et al. 1979). But this indicator, observed at the grazed field level, does not provide enough information in advance about the grazing area needed to match the recommendation on each of the grazed fields, i.e., to permit the anticipation of a possible change due to an excess or a lack of grass. It does not give any indication if the size of the whole grazing area is designed to achieve a high grazing efficiency, as defined by Scarnecchia $(1988,1994)$. Furthermore, it is difficult to assess in a simple way the respective effect of grazing intensity and nitrogen supply on the stocking rate at the farm enterprise level.

The intensity and frequency of sward defoliation determines both the net herbage growth following a grazing and herbage intake (Parsons 1988). These practices also determine the efficiency of fertilizer use, nitrogen in particular (Mazzanti et al. 1994). Numerous studies have shown that high grazing intensity is necessary to optimize the balance between the uptake of herbage which depends mainly on stocking rate, and the loss of herbage, which depends mainly on the amount of residual herbage mass. In this way, the stocking rate is a driving variable used to optimize herbage production and consumption, rather than an aim (Hodgson 1985). From a practical point of view, a target height $(\mathrm{H})$ is recommended to manage a continuous graz- 
ing system. For a given stocking rate ( $\mathrm{N}$ animals on an area A), this rule corresponds to a sward volume per animal, i.e., $\mathrm{A} * \mathrm{H} / \mathrm{N}$. The sward height or the herbage volume per animal are the result of 3 fluxes: growth, consumption and senescence. The growth depends mainly on nitrogen and climatic variables. The consumption and senescence fluxes are maximized and minimized respectively for the target height. For perennial ryegrass swards, with high nitrogen supply, the sward height recommendations are accurate (Hodgson 1985, Parsons 1988). They vary according to the field and the animal type (Le Du et al. 1981, Maxwell et al. 1994). For other forms of grazing management than continuous grazing, there is not such a global indicator which allows one to decide how much grazing area to add or to remove to maintain a high grazing intensity on a set of grazed fields throughout a growing season. Using a simulation model to compare continuous and intermittent defoliation, Parsons et al. (1988) concluded that for a rotational grazing system, sward management would need an average state to be calculated in practice. This is why we hypothesized that a method which takes into account the sward state at the whole grazing area level could usefully supplement the usual indicators. Furthermore, previous studies have shown that some farmers already use such an empirical method, based on the herbage volume per animal measured on all the grazed fields in the same time, throughout a growing season (Duru et al. 1988). The aim of this study is to explain this type of methodolo$\mathrm{gy}$, and to analyze if it is relevant to manage a rotational grazing system.

Using a simple model of herbage growth, we analyze the relationship between net herbage accumulation at field level and available herbage per animal at the whole grazing area level, to identify if the residual sward height is a relevant variable at the both levels. To assess the value of this approach, we collected data on a set of grazing systems (herbage nitrogen status, stocking rate, herbage volume per animal) and among them on a set of grazed fields (herbage mass).

\section{Materials and methods}

\section{Model of net herbage accumulation at grazed field level}

The nutritional status of herbage depends on the previous management of the swards and on the fertilizer applied. To assess $\mathrm{N}$ status, we used the "dilution curve" method (Lemaire and Salette 1984). During herbage regrowth, the nitrogen concentration decreases as the aboveground dry matter increases $\mathrm{N} \%=\alpha \mathrm{HM}^{-\beta}$, $\mathrm{N}$ being the nitrogen concentration in $\mathrm{g}$ $100 \mathrm{~g}^{-1}, \mathrm{HM}$ the above-ground herbage mass in tonnes of dry matter per ha, $\alpha$ the nitrogen concentration when $\mathrm{HM}=1 \mathrm{t} \mathrm{ha}^{-1}$, $\beta$ the coefficient of nitrogen dilution. With optimum nitrogen nutrition, the $\alpha$ and $\beta$ parameters are the same no matter what the year or the species, even for legumes: $\alpha=$ 4.8 and $\beta=0.32$ (Lemaire and Gastal 1997, Duru et al. 1997). We used the parameters of this control curve to calculate an index for herbage nitrogen status (Ni) taken as the ratio between the measured $\mathrm{N}$ concentration $(\mathrm{N})$ of the above-ground herbage mass matter (HM) and the optimum N concentration as previously defined, (Lemaire and Gastal 1997):

$$
\mathrm{Ni}=100 * \mathrm{~N} / 4.8 \mathrm{HM}^{-0.32}
$$

When the index was equal to 100 , it indicated a non-limiting nitrogen status of the sward.

To establish a model of net herbage accumulation between post and pre-grazing times, we selected variables which influence growth : herbage nitrogen index, accumulated temperatures and accumulated incident radiation between 2 defoliations (Bélanger et al. 1992) and those which favored senescence. The residual herbage mass limits the amount of intercepted radiation when it is low, but increases the daily senescent herbage when it increases (Parsons et al. 1988). In our case, we considered that it did not limit the amount of radiation intercepted because in most cases, it was greater than $1 \mathrm{t} \mathrm{ha}^{-1}$. Knowing pluviometry, evapotranspiration and an assessment of the soil water capacity, we show that there was no drought over the studied grazing seasons.

Net herbage accumulation $=$ growth senescence $=\mathrm{f}(\mathrm{Ni}, \mathrm{HMr}, \mathrm{Tac}, \mathrm{Rac})$

$\mathrm{Ni}$ : herbage nitrogen index, HMr: residual herbage mass, Tac and Rac: respectively accumulated temperatures and incident radiation between 2 defoliations

\section{Relationship between herbage mass per animal and stocking rate at the whole grazing area level, and resid- ual herbage mass at field level}

We expressed the herbage mass per animal unit in relation to sward management variables defined at the whole grazing area level (stocking rate, number of animals) or averaged at the grazed field level : herbage mass (defined as the average between dry matter before and after grazing), herbage nitrogen status and residual herbage at the grazed plot level A, a and b being constants:

herbage mass animal ${ }^{-1}=$ herbage mass

$\mathrm{ha}^{-1} /$ animal ha ${ }^{-1}$

average herbage mass $\mathrm{ha}^{-1}=$ residual herbage ha-1 + (residual herbage $\mathrm{ha}^{-1}+$ net growth $\left.\mathrm{ha}^{-1}\right) / 2$

stocking rate $=$ animal ha- $\mathrm{ha}^{-1} \mathrm{~A}^{*}$ net herbage accumulation $\mathrm{ha}^{-1}$

using eq 5 ,

herbage mass animal ${ }^{-1}=\left(1.5^{*}\right.$

residual herbage ha ${ }^{-1}+0.5 *$ net

herbage accumulation growth $\left.\mathrm{ha}^{-1}\right) /$

(A* net herbage accumulation

$\mathrm{ha}^{-1}$

herbage mass animal ${ }^{-1}=\left(\mathrm{a}^{*}\right.$

residual herbage $\mathrm{ha}^{-1} /$ net herbage

accumulation growth $\left.\mathrm{ha}^{-1}\right)+\mathrm{b}$

herbage mass animal ${ }^{-1}=\left(a^{*}\right.$

residual herbage ha $^{-1} /$ stocking

rate) $+b$

\section{The data}

The study was done in the south-west of France (Aveyron department : $49^{\circ} 15^{\prime} \mathrm{N}$, $0.30^{\circ} \mathrm{E}$ ) on 2 dairy cow farms (Holstein breed) and 2 dairy ewe commercial farms (Lacaune breed) at an altitude of $600 \mathrm{~m}$ and within $50 \mathrm{~km}$ of each other. For each livestock type, one of each location, farms were chosen to have different stocking rates at the beginning of the study (Bossuet and Duru 1994). Farms were labeled both with a letter and a number : $\mathrm{C}$ (cow) or E (ewe), 1 (highest stocking rate), 2 (lowest stocking rate). The results given here are only for data collected from 1992 to 1994.

Calving was in autumn (September, October) and lambing in winter (December), so animals were dry in summer. The field pattern was usually scattered, and fields were small (less than 2 ha), which imposed a rotational grazing system. Soils are loamy sand and well drained. Grasses were the most common species in these natural or permanent grasslands, and cocksfoot (Dactylis glom erata L.) is the commonest grass.

Indoor feeding was mainly with maize silage. It was on average greater for ewe than for cow systems during the grazing season (Table 1). However, the average amounts varied greatly throughout the grazing season. The grazing area varied more or less according to the livestock farm and the season as indicated by the minimum and the maximum values observed in the different grazing cycles throughout the grazing season. The differ- 
Table 1. Livestock farms characteristics and grazing management for commercial farms (C: cow, E: ewe, Number 1 and 2) and grazing seasons from turnout date up to the middle of July) ; Ma: March, Ap: April.

\begin{tabular}{|c|c|c|c|c|c|c|c|c|c|c|c|c|}
\hline \multirow{2}{*}{$\begin{array}{l}\text { Livestock farm } \\
\text { Growing seasons }\end{array}$} & \multicolumn{3}{|c|}{$\mathrm{Cl}$} & \multicolumn{3}{|c|}{$\mathrm{C} 2$} & \multicolumn{3}{|c|}{ E1 } & \multicolumn{3}{|c|}{ E2 } \\
\hline & $\overline{1992}$ & 1993 & 1994 & $\overline{1992}$ & 1993 & 1994 & 1992 & 1993 & 1994 & 1992 & 1993 & 1994 \\
\hline Number of Animal Unit (AU) & 32 & 31 & 27 & 46 & 51 & 60 & 32 & 30 & 26 & 54 & 60 & 56 \\
\hline Silage $\left(\mathrm{kg} \mathrm{day}^{-1} \mathrm{AU}^{-1}\right)$ & 2.5 & 1.0 & 2.9 & 2.5 & 4.3 & 2.9 & 7.3 & 6.0 & 6.1 & 10.5 & 4.8 & 8.2 \\
\hline Number of grazing cycles ${ }^{b}$ & 4 & 4 & 4 & 5 & 6 & 5 & 4 & 5 & 6 & 4 & 4 & 4 \\
\hline Average number of fields ${ }^{b}$ & 6 & 6 & 5 & 9 & 5 & 8 & 6 & 6 & 5 & 6 & 6 & 5 \\
\hline Nitrogen supply $\left(\mathrm{kg} \mathrm{ha}^{-1}\right)$ & 100 & 90 & 105 & 70 & $6-$ & 70 & 50 & 40 & 70 & 70 & 60 & 55 \\
\hline
\end{tabular}

aminimum and maximum values according to the grazing cycle

${ }^{b}$ for plots used over the full grazing period

ence between the minimum and the maximum was particularly high for the $\mathrm{C} 2$ system. The number of grazing cycles varied from 4 to 6 , and the number of grazed fields over the grazing season varied from 5 to 8 (Table 1). The average number of grazing days per field varied from 2 to 5 , according to the field size. The amount of nitrogen supply varied from 40 to $105 \mathrm{~kg} \mathrm{ha}^{-1}$

Measurements and data collection were applied both to the whole grazing area and animal feeding in spring, and to 3 specific grazed fields. Measurements were made from the middle of March until the beginning of July. At the grazing season level, we recorded the number of grazing animals, the fields used for grazing, the amount of nitrogen applied, and the indoor feeding (silage, concentrates) every 3 weeks, at the time of surveys. Herbage height was measured on all grazed fields expected to be used, 6, 8, and 11 times respectively in 1992 1993, and 1994. For reasons of convenience and speed, we used a sward-stick (Bircham 1981), which was automated (Duru and Ducrocq 1998). On each grazed field, a transect was laid down. Measurements were made 5 to 7 meters apart, corresponding to about 35 data per ha. At the end of the study period, we assembled the grazing plans to know which fields were effectively grazed to calculate the stocking rate and the herbage volume on the whole grazed fields.

Within each of the livestock farms, we sampled 3 fields which were not consecutively grazed, but which were to be used during the grazing season. Throughout the length of a 30 meter transect, marked with permanent sticks, sward height was measured and herbage was weighed (4 subplots of $0.25 \mathrm{~m}^{2}$ ) after cutting at $2 \mathrm{~cm}$ above ground level with a small clipping machine. These subplots were distributed along the transect, each time at different places, just before or after animals grazed. To assess the residual herbage mass at the beginning of the grazing season, the first measurement was taken at the middle of March. Each sample was dried at $80^{\circ} \mathrm{C}$ for 48 hours to assess the above-ground dry matter, then milled through a $0.8 \mathrm{~mm}$ screen to analyze total nitrogen content (Kjeldahl procedure).
Average daily radiation, temperature, and rainfall were recorded on each of the 2 locations. Data were similar between the 2 locations. For the cow farm locations, the average temperatures are shown in Fig. 1. For the 3 study periods, the rainfall was 558,493 , and $450 \mathrm{~mm}$ from 1 April to 20 July, respectively in 1992,1993 , and 1994.

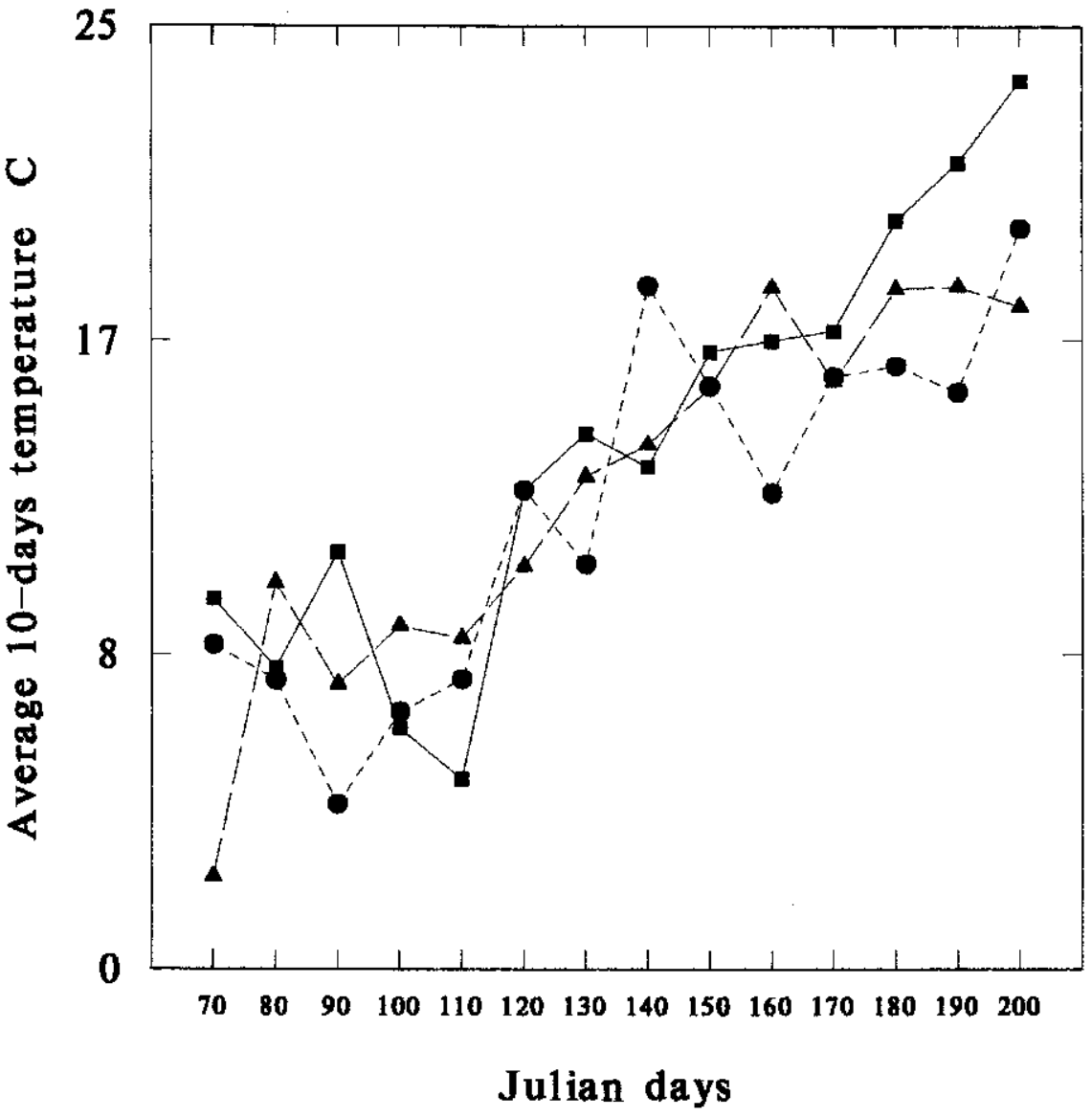

Fig. 1. Average 10-days air temperature on the cow-location for the 3 growing seasons: 1992 $\bullet, 1993 \Delta$ and $1994 \square$. 


\section{Data calculation and statistical analysis}

To have a simple and practical indicator, we used sward height instead of sward mass at grazed field and whole grazing area levels. Sward heights were measured from soil level. However, to compare grazing systems with different stocking rates, we adjusted them to a $5 \mathrm{~cm}$ base to get closer to the herbage available in grazing conditions (no measurements below this height). Detailed studies showed that the variability of the herbage density $(\mathrm{HM} / \mathrm{H})$ between fields was reduced if the residual layer of herbage was not included (Duru and Ducrocq 1998).

The interval between 2 defoliations was expressed in degree-days (dd using $0^{\circ} \mathrm{C}$ as base temperature), because leaf blade growth and its lifespan depends mainly on temperature (Gastal et al. 1992). For the first grazing cycle, we used the first date of sward measurement, and the herbage biomass at this date was regarded as residual herbage mass.

To calculate the net stocking rate, we found a common basis to compare the cow and ewe livestock farms. We chose 1 cow $=7$ ewes $=1$ animal unit (AU), (Jarrige 1978). Second, to assess the grazing contribution to feed animals, we assumed that the average daily intake per AU is $15 \mathrm{~kg}$ of dry matter (Hoden et al. 1986).

A 2-way analysis of variance was performed to compare grazing management between livestock farms and grazing seasons (net stocking rate, herbage volume per ha or per animal) and sward states (herbage nitrogen status), in which the different sampling dates were considered as replicates.

\section{Results}

\section{Herbage measurements on the three sampling fields}

The residual herbage mass varied greatly. For $80 \%$ of the data (extreme values excluded), the values were between 125 and $400 \mathrm{gm}^{-2}$ (Fig. 2a). On an average, they were lowest for the first grazing cycle. They were very variable for each of the fields since the coefficient of variation between the different measurements done on a given field was, in each grazing season, greater than $50 \%$ for 8 of the 12 fields. Similarly, the residual sward height varied from 7.5 to $15 \mathrm{~cm}$ (Fig. 2b). The interval between 2 defoliations was very variable. For $90 \%$ of the data, it varied from 100 to 400 degree-days (Fig. 2c). The net herbage accumulation between
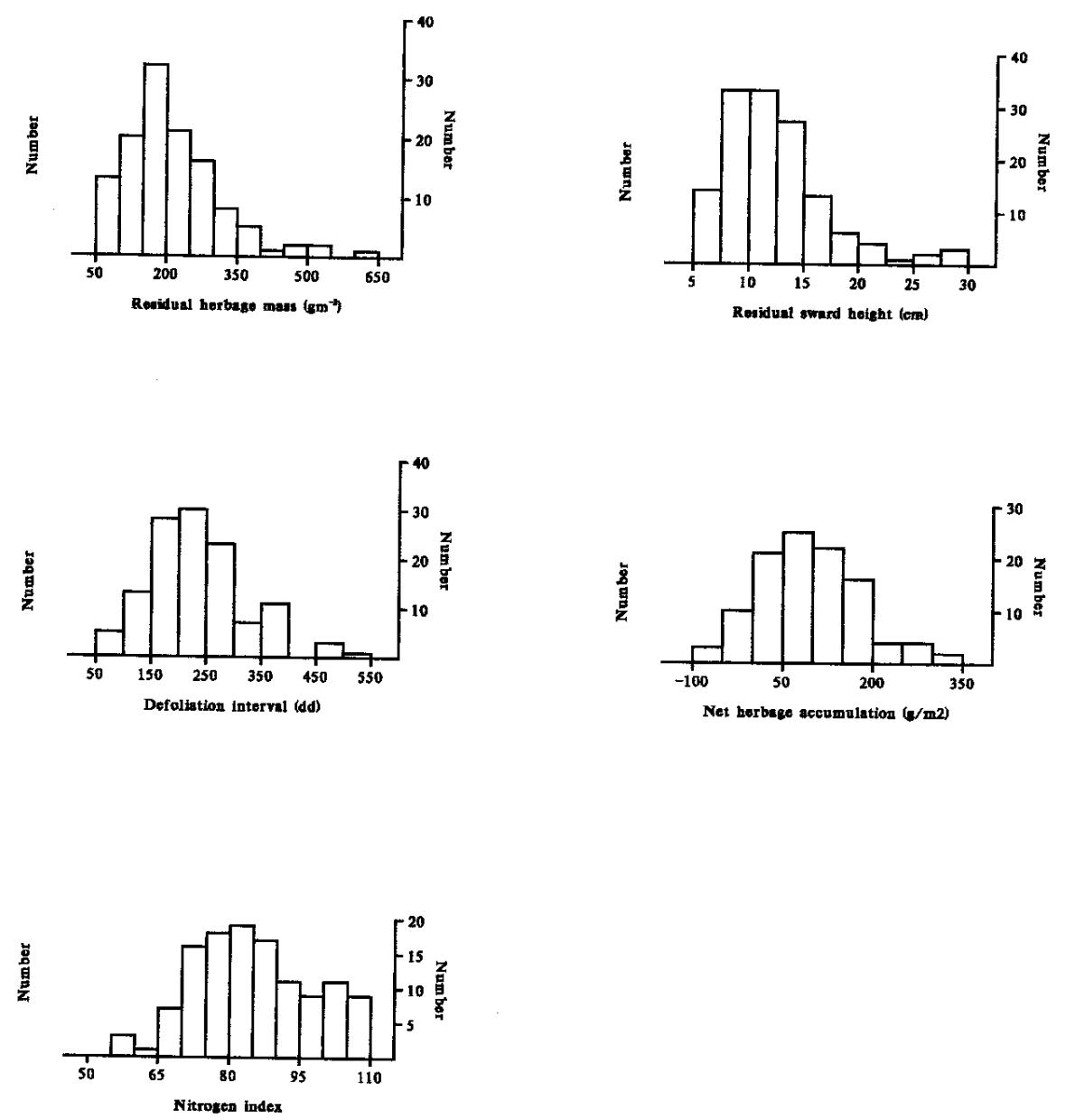

Fig. 2. Frequency distribution of the main sward characteristics and management at field grazed level.

post and pre grazing was negative for $10 \%$ of the grazing cycles (Fig. 2d).

The herbage nitrogen index was usually between 70 and 90 (Fig. 2e). It was on an average highest for the first grazing cycle, then decreased for the others $(\mathrm{P}<0.001)$. There was a significant relationship between the herbage nitrogen index and the nitrogen supply on each field ( $\mathrm{P}<$ $0.01)$, but the coefficient of correlation was low $(r=0.49)$.

We used field data in Equation 2 to determine the significance of management and climate variables on the net herbage accumulation (NHA) between post and pre-grazing time. Using a stepwise regression, we found the following relationship $\left(r^{2}=0.56, n=121, \mathrm{RSR}=62\right)$; where $\mathrm{Ni}$ is a herbage nitrogen index, $\mathrm{HMr}$ (residual herbage mass) and NHA were expressed in gm-2 and Tac (accumulated temperatures between 2 defoliations) in degreedays:

$\mathrm{NHA}=-116-0.42 \mathrm{HMr}+2.80$

$\mathrm{Ni}+0.29 \mathrm{Tac}$
As expected, there was a positive effect of the herbage nitrogen index and a negative effect of the residual herbage mass $(\mathrm{P}$ $<0.05)$. The effect of incident radiation was not significant. For Tac $=250$ (average observed value), NHA was equal to zero or became negative when $\mathrm{HMr}=430$ $(\mathrm{Ni}=80)$ or $360 \mathrm{gm}^{-2}(\mathrm{Ni}=70)$.

\section{Sward characteristics and grazing management over the whole grazing period and area}

In the first growing season, the net stocking rate was greater for livestock farms Number 1 than those of Number 2, in accordance with a previous study (Bossuet and Duru 1994). It was the highest and most regular for the cow farm Number 1. It was also for this farm that the amount of silage used was the lowest. For the 3 other farms, the stocking rate was lower and more variable over the 3 growing seasons. There was a significant effect of the livestock farm and its interaction with the growing season (Table 3 ). 
Table 2. Average sward characteristics over the grazing period (from turnout date up to the middle of July) according commercial farms (C: cow, E: ewe, Number 1 and 2) and grazing seasons.

\begin{tabular}{|c|c|c|c|c|c|c|c|c|c|c|c|c|c|}
\hline \multirow{2}{*}{\multicolumn{2}{|c|}{$\begin{array}{l}\text { Livestock farm } \\
\text { Growing seasons }\end{array}$}} & \multicolumn{3}{|c|}{$\mathrm{Cl}$} & \multicolumn{3}{|c|}{$\mathrm{C} 2$} & \multicolumn{3}{|c|}{ E1 } & \multicolumn{3}{|c|}{ E2 } \\
\hline & & 1992 & 1993 & 1994 & 1992 & 1993 & 1994 & 1992 & 1993 & 1994 & 1992 & 1993 & 1994 \\
\hline $\begin{array}{l}\text { Net Stocking rate (AU) } \\
\text { AU ha }\end{array}$ & $\begin{array}{l}\mathrm{m} \\
\mathrm{se}\end{array}$ & $\begin{array}{l}4.6 \\
0.53\end{array}$ & $\begin{array}{l}4.6 \\
0.34\end{array}$ & $\begin{array}{l}4.7 \\
0.75\end{array}$ & $\begin{array}{l}2.8 \\
0.39\end{array}$ & $\begin{array}{l}2.4 \\
0.33\end{array}$ & $\begin{array}{l}3.8 \\
0.61\end{array}$ & $\begin{array}{l}3.6 \\
0.68\end{array}$ & $\begin{array}{l}3.2 \\
0.21\end{array}$ & $\begin{array}{l}2.3 \\
0.44\end{array}$ & $\begin{array}{l}2.3 \\
0.34\end{array}$ & $\begin{array}{l}3.5 \\
0.49\end{array}$ & $\begin{array}{l}2.6 \\
0.53\end{array}$ \\
\hline $\begin{array}{l}\text { Herbage volume }_{0} * \\
\left(\mathrm{~m}^{3} \mathrm{ha}^{-1}\right)\end{array}$ & $\begin{array}{l}\mathrm{m} \\
\mathrm{se}\end{array}$ & $\begin{array}{l}1847 \\
80\end{array}$ & $\begin{array}{l}1743 \\
152\end{array}$ & $\begin{array}{l}1918 \\
170\end{array}$ & $\begin{array}{l}2205 \\
217\end{array}$ & $\begin{array}{l}1560 \\
95\end{array}$ & $\begin{array}{l}1807 \\
143\end{array}$ & $\begin{array}{l}1231 \\
125\end{array}$ & $\begin{array}{l}1362 \\
133\end{array}$ & $\begin{array}{l}1486 \\
108\end{array}$ & $\begin{array}{l}1826 \\
111\end{array}$ & $\begin{array}{l}1599 \\
103\end{array}$ & $\begin{array}{l}1441 \\
84\end{array}$ \\
\hline $\begin{array}{l}\text { Herbage volume }{ }_{5}^{*} \\
\left(\mathrm{~m}^{3} \mathrm{AU}^{-1}\right)\end{array}$ & $\begin{array}{l}\mathrm{m} \\
\mathrm{se}\end{array}$ & $\begin{array}{l}321 \\
25\end{array}$ & $\begin{array}{l}271 \\
32\end{array}$ & $\begin{array}{l}341 \\
39\end{array}$ & $\begin{array}{l}614 \\
114\end{array}$ & $\begin{array}{l}514 \\
47\end{array}$ & $\begin{array}{l}384 \\
31\end{array}$ & $\begin{array}{l}256 \\
30\end{array}$ & $\begin{array}{l}298 \\
31\end{array}$ & $\begin{array}{l}403 \\
65\end{array}$ & $\begin{array}{l}600 \\
125\end{array}$ & $\begin{array}{l}299 \\
62\end{array}$ & $\begin{array}{l}644 \\
195\end{array}$ \\
\hline Herbage nitrogen index & $\begin{array}{l}\mathrm{m} \\
\mathrm{se}\end{array}$ & $\begin{array}{l}96 \\
4.6\end{array}$ & $\begin{array}{l}90 \\
4.7\end{array}$ & $\begin{array}{l}93 \\
4.5\end{array}$ & $\begin{array}{l}80 \\
2.8\end{array}$ & $\begin{array}{l}76 \\
2.4\end{array}$ & $\begin{array}{l}87 \\
4.8\end{array}$ & $\begin{array}{l}74 \\
3.0\end{array}$ & $\begin{array}{l}84 \\
3.2\end{array}$ & $\begin{array}{l}83 \\
2.5\end{array}$ & $\begin{array}{l}77 \\
1.2\end{array}$ & $\begin{array}{l}68 \\
3.1\end{array}$ & $\begin{array}{l}76 \\
4.0\end{array}$ \\
\hline
\end{tabular}

Mean (m), standard error (se) calculated from the different sampling dates; AU animal unit; ${ }^{*}$ sward height base (0 or $\left.5 \mathrm{~cm}\right)$ to calculate herbage volume.

The average herbage volume per ha varied greatly over livestock farms and growing seasons. Generally it was lower for ewe farms. There was a significant effect of livestock farm, growing season and their interaction.

The average herbage volume per AU was the lowest and the most regular between sampling dates for cow farm Number 1. It was about twice as much for cow farm Number 2. On other farms, the stocking rate was lower and more variable over the 3 growing seasons. There was a significant effect of the livestock farm and its interaction with the growing season (Table 3). For cow farm Number 2 and the 2 ewe farms, there was a trend of net stocking rate increase as the herbage volume per AU decreased (Table 2).

The herbage nitrogen status was highest and most uniform for cow farm Number 1, corresponding with the stocking rate. It was lower for the 3 other livestock farms. There was a significant effect of the livestock farm and its interaction with the growing season (Table 3 ).

Collecting data over 3 grazing seasons allows us to assess the regularity of the grazing management. We observed it was very stable for the cow farm Number 1 and that it varied considerably for the cow farm Number 2, where the stocking rate increased by more than $50 \%$ and the herbage volume per animal decreased by about $50 \%$. The stocking rate and the herbage volume per AU changed the most on the cow farm Number 2 (Table 2).

We compared the net stocking rate, calculated on the whole grazing area, and the net herbage accumulation on the 3 studied fields (eq 5). There was a significant relationship between the 2 variables $\left(r^{2}=0.47\right.$, $\mathrm{P}<0.01$, Fig. 3). This is a way to assess the consistency of the simplifications we made previously when we assessed the grazing contribution to the animals' diet, subtracting the amount of silage supplied. Figure 3 shows the line corresponding to a daily herbage consumption of $15 \mathrm{~kg}$ per
Table 3. Levels of significance of the effects of livestock farm, growing season and their interactions on the components of herbage management and sward characteristics

\begin{tabular}{lccc}
\hline \hline & Livestock farm & Growing season & $\begin{array}{c}\text { Livestock farm * } \\
\text { growing season }\end{array}$ \\
\hline Net stocking rate $\left(\mathrm{AU} \mathrm{ha}^{-1}\right)$ & $* * *$ & $\mathrm{~ns}$ & $* * *$ \\
Herbage volume $_{0}{\mathrm{a}\left(\mathrm{m}^{3} \mathrm{ha}^{-1}\right)}^{\text {Herbage volume }}{\mathrm{a}\left(\mathrm{m}^{3} \mathrm{AU}^{-1}\right)}^{-1}$ & $* * *$ & $*$ & $* * *$ \\
Herbage nitrogen index & $* * *$ & $\mathrm{~ns}$ & $* * *$ \\
\hline
\end{tabular}

$* \mathrm{P}<0.05$, ** $\mathrm{P}<0.01, * * * \mathrm{P}<0.001, \mathrm{~ns}$ non significative; $\mathrm{AU}$ : animal unit; a sward height base $(0$ or $5 \mathrm{~cm})$ to calculate herbage volume.

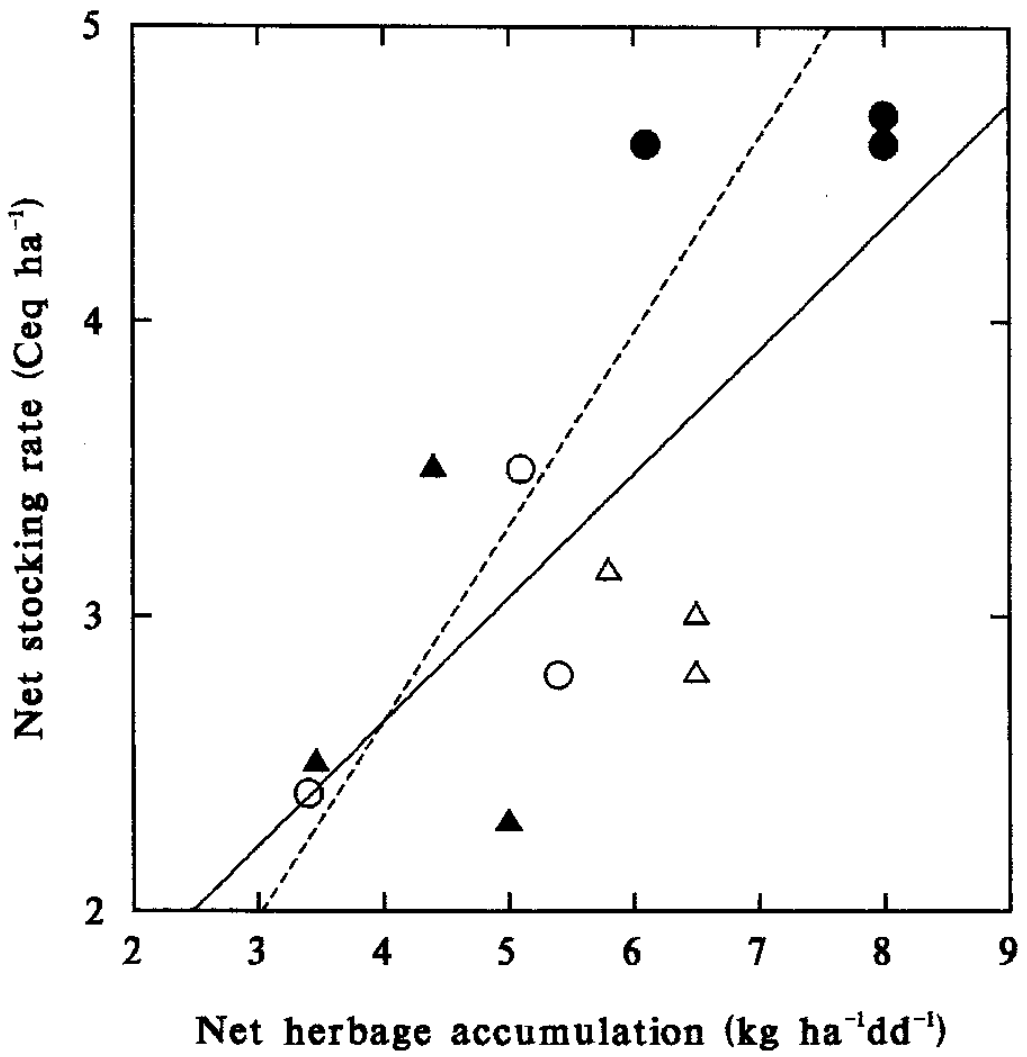

Fig. 3. Relationships between net stocking rate (whole grazing period) and net herbage accumulation rate ( $\mathrm{kg} \mathrm{ha}^{-1}$ and degree-days, data collected on 3 grazed plots); one data point per livestock farm $(\mathrm{Cl} \bullet, \mathrm{C} 2 \bigcirc, \mathrm{El} \Delta, \mathrm{E} 2 \Delta)$; the broken line represents a daily herbage intake of $15 \mathrm{~kg}$ per cow (Y axis * 15) versus a net herbage accumulation rate for an average temperature of $10^{\circ} \mathrm{C}(\mathrm{x}$ axis $* 1)$. 


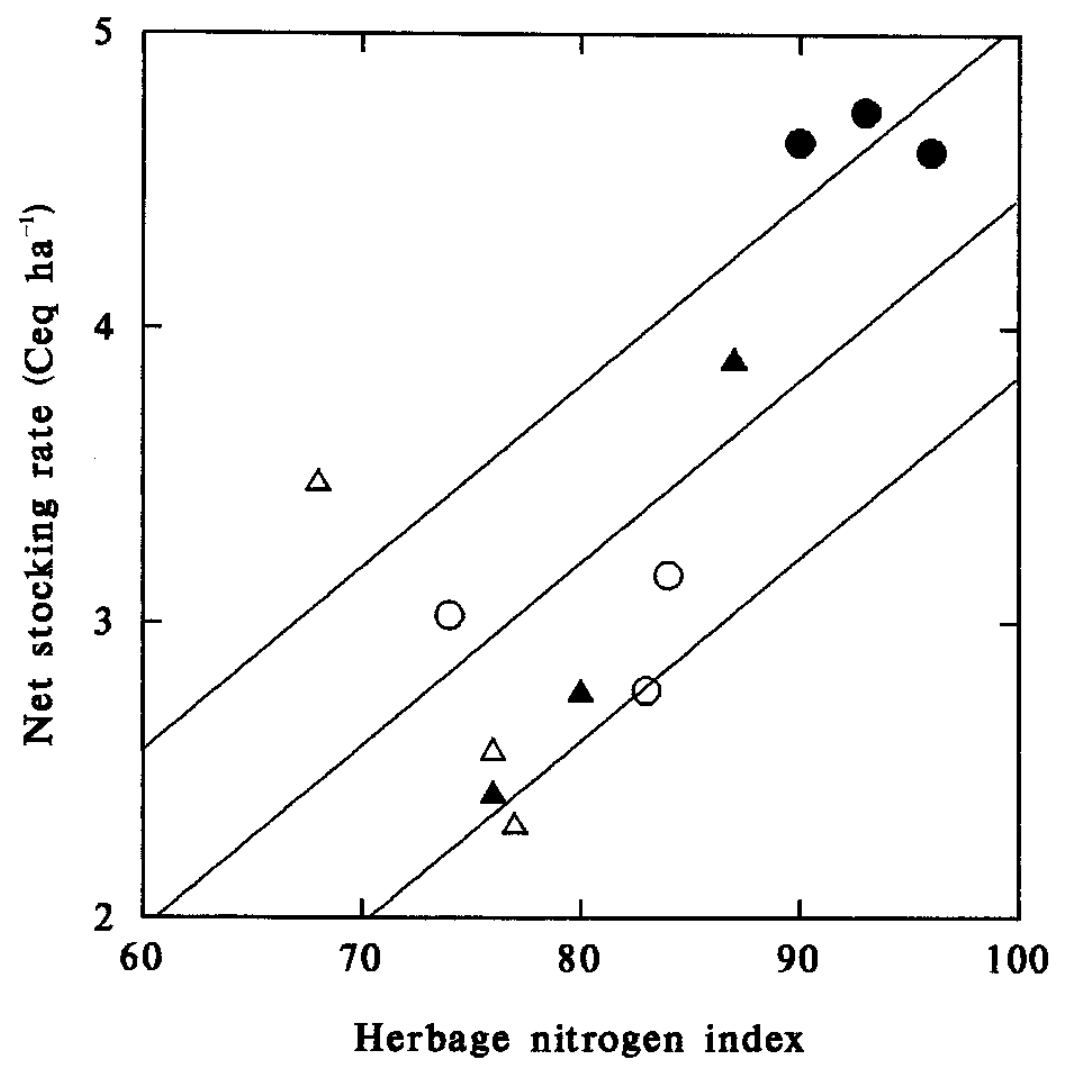

Fig. 4. Relationship between the net stocking rate and the herbage nutrient index; lines drawn represent the herbage volume per Cow equivalent $(1 \mathrm{AU}=1$ cow or 7 ewes) respectively 200, 400 and $600 \mathrm{~m}^{3} \mathrm{AU}^{-1}$ from top to bottom; livestock farms : Cl •, C2 O, El $\triangle, \mathrm{E} 2$ $\Delta$.

AU ( $\mathrm{Y}$ axis $* 15)$ in relation to the net growth for an assumed daily temperature of $10^{\circ} \mathrm{C}$ ( $\mathrm{X}$ axis $\left.* 10\right)$. The 2 lines do not differ very much. Differences could result from errors in the assessment of feed silage supply or daily intake.

As we did previously for the net herbage accumulation, we establish a model of the net stocking rate over the grazing season, selecting factors which influenced growth (herbage nitrogen index, average temperature) and those which favored senescence (herbage volume per AU). As we see in Figure 4 , the net stocking rate was negatively correlated with the herbage volume per AU. Using a stepwise regression, we found the following relationship ( $\mathrm{Ni}$ herbage nitrogen index, $\mathrm{HV}_{5} \mathrm{AU}^{-1}$ herbage volume ( $5 \mathrm{~cm}$ basis) per Animal Unit $\left.\mathrm{r}^{2}=0.64, \mathrm{n}=12, \mathrm{RSR}=0.53\right)$ :

Net stocking rate $=-0.23+0.06$ $\mathrm{Ni}-0.003 \mathrm{HV}_{5} \mathrm{AU}^{-1}$

As defined in theory (eq 8), we verified if there was a significant relationship between herbage volume per animal unit and residual herbage mass. We found:

$\mathrm{HV}_{5} \mathrm{AU}^{-1}=78 \mathrm{Hs} /$ net stocking

rate $+103 ; r^{2}=0.78(\mathrm{P}<0.001)$ each livestock farm and growing season (Fig. 5a). We concluded that in the present study the sward height was on average a satisfactory indicator to assess the herbage mass at the livestock farm and the whole grazing season levels.

Were the 3 fields studied representative of the overall grazing area?

The number of grazing days on the 3 fields studied represent about $50 \%$ of the total grazing days over the study period for the cow farm Number 1 and the 2 ewe farms and about $35 \%$ for cow farm Number 2 . There is a close relationship between the average herbage volume per ha and the average sward height on the 3 fields (Fig. $5 b), r^{2}=0.68, P<0.001, R S R=150$. These 2 independent sets of data indicate that the 3 fields could be considered representative of the whole grazing area.

\section{Discussion and Conclusion}

\section{Effect of grazing management on net herbage accumulation}

The 3 studied fields could be considered as representative of the whole grazing area. This allows us to use herbage nitrogen status for modeling stocking rate according to data collected at the whole grazing area level.

Using the statistical model, the herbage accumulation rate was positively correlated with herbage nitrogen status as observed in many studies (Bélanger et al. 1992, Duru et al. 1995). According to these authors, this parameter is a basis for assessment of the actual herbage accumulation rate compared with the potential one. For the cow farm Number 1 where the $\mathrm{N}$ index was close to 100 , there is no justification for increasing the stocking rate by giving more nitrogen. The fact that incident radiation was not found to be important in regression analysis could be because it was correlated with temperature. The negative relationship with the residual herbage mass could have 2 causes. First, the length of leaves which become senescent is directly proportional to the residual herbage mass through their lifespan (Davies 1988), which is usually rather constant for a given species when expressed in degree-days (Duru et al. 1993). Second, part of the respiration depends on plant mass, about $1.5 \%$ per day (Parsons 1988). So, for a given herbage nitrogen index, the net herbage accumulation per day should be lower when the residual herbage mass increases. However, we might qualify this view, as a 

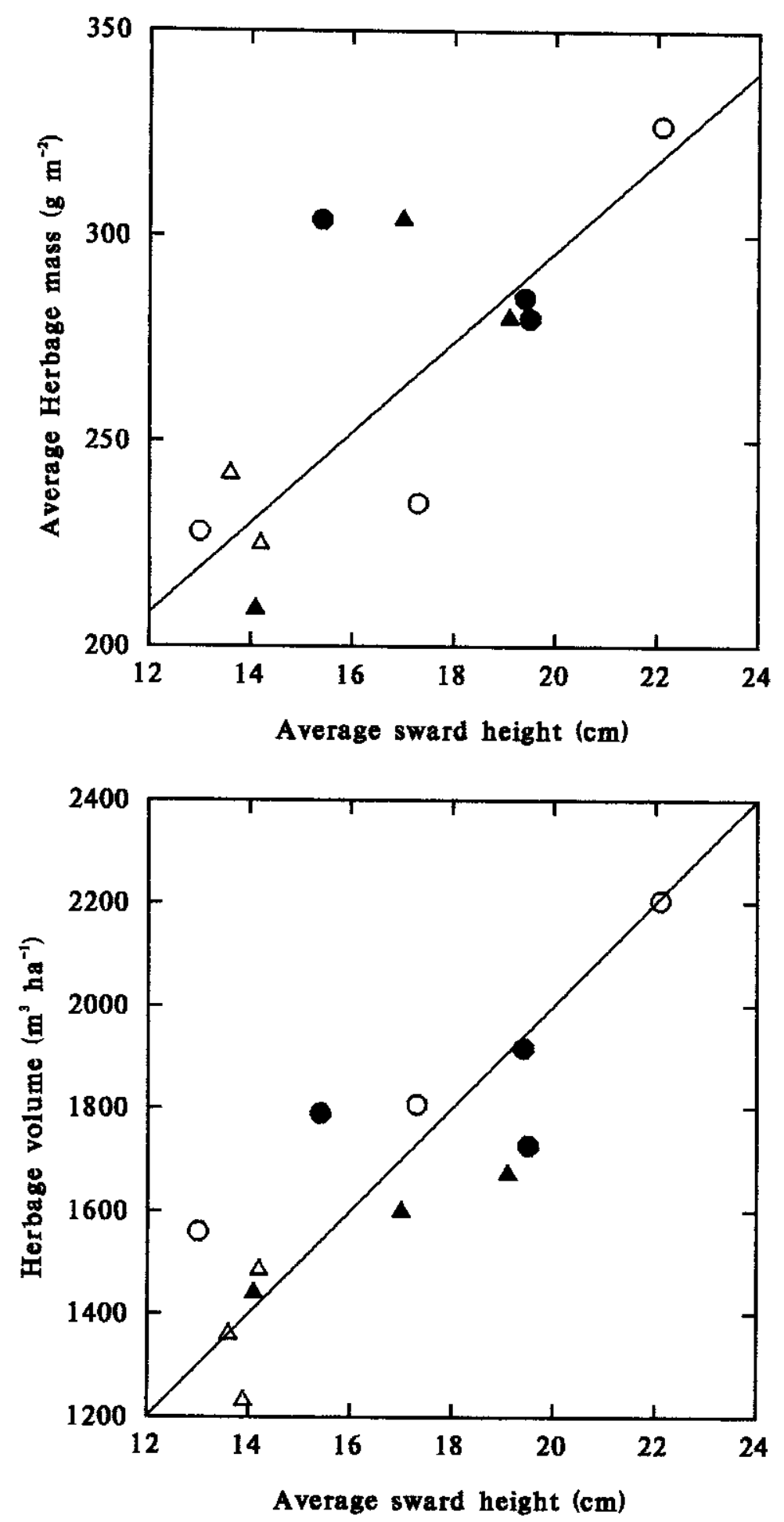

Fig. 5. Average herbage mass and average sward height (mean of pre and post grazing measurements on 3 grazing plot per farms) (Fig 5a), herbage volume (whole grazing area) and average sward height ( 3 grazing plots) (Fig $5 \mathrm{~b}$ ) ; one data point per livestock farm $(\mathrm{Cl} \bullet, \mathrm{C} 2$ $\mathrm{O}, \mathrm{El} \Delta, \mathrm{E} 2 \Delta$ ) and grazing season, full line were linear fitting between the 2 variables.

lower residual herbage mass could limit the radiation interception. But in our case, residual herbage mass was normally high (Fig.2), so that it would not limit the radia- tion interception, as shown by measurements in most of these fields (Ducrocq, unpublished data). These results were in agreement with those of Mayne et al.
1987, which showed that most often the net herbage accumulation decreases when the residual sward height increases. This means that for the livestock farms studied, the net stocking rate or the net herbage accumulation rate should be greater, for the same amount of applied $\mathrm{N}$, if the residual bioinass is lower.

There is a trend towards an increase in grazing efficiency when the herbage volume per AU decreases. The available herbage volume per $\mathrm{AU}$ is an indicator of the efficiency of grazing management. It reflects, at the whole grazing season and area levels, how the system works in average on 1 grazed field over 1 grazing cycle. Indeed, the main variables which were selected to express the net herbage accumulation rate (field level) or the stocking rate (whole grazing area level) were the same at the 2 levels.

\section{Herbage volume per animal unit for monitoring and assessing of a rota- tional grazing system}

The great variability of stocking rate, particularly on commercial farms, was observed previously (Peel et al. 1988). In this study, the highest values of utilized metabolizable energy output were not always obtained at higher fertilizer $\mathrm{N}$ inputs, but more often on the more flexible system. Such assessments at commercial farm level point towards the need for tools for successful integration of rotational grazing into livestock farming. This implies close integration of grazing with cutting for conservation and a very flexible approach which could result in the area and quantity of herbage cut for conservation varying widely from year to year, according to growing conditions (Wilkins, 1995). In this area, the herbage volume per animal unit should be considered as a global state variable resulting of rates of herbage growth, disappearance, and intake, rates which could be used as indicators in grazing research and management.

For monitoring a rotational grazing system, the observation of the residual herbage mass is insufficient to decide when to add or to remove a grazed field. Firstly, under such a system, the degree to which animals harvest the accumulated herbage is unpredictable, compared with cutting or continuous grazing, and sometimes leads to relatively light defoliation (Parsons et al. 1988). This is particularly true when the size of the grazed fields is small and differs within the grazing area, allowing only a few and variable number of grazing days on each of them, as in our study. Secondly, the residual herbage mass 
does not provide an overview of the grazing system a few days ahead, to permit the anticipation of a possible change due to an excess or a lack of grass. The herbage volume per animal unit could do this, and in this way, possible errors due to an assessment of the sward state on a particular grazed field could be avoided. This is why the periodical assessment of the sward state at the whole grazing area level could be used as a supplementary indicator to decide the number of grazed fields to get through the grazing period. From a practical point of view, the need is to define an optimal herbage volume. There are 2 limitations with our set of data. First, the relationship between sward height and sward mass depends greatly on the species and the sward structure on one hand and on the tool used to measure the sward height (sward stick, plate meter) on the other. Further studies must be done to provide accurate recommendations for a large range of species and sward structures (Duru and Ducrocq 1998). Secondly, there was not a complete "stocking rate $\mathrm{x}$ herbage nitrogen status" design, and above all, the herbage volume varied too much throughout the grazing season. We only aim to give an approximate herbage volume per animal unit assuming optimal grazing management. Experiments could be used to complete the comparison of commercial farms. Past results are available for this purpose.

The herbage volume per animal unit could be also a tool to assess a posteriori the efficiency of the grazing system. Knowing only the grazing calendar (turnout date, interval between 2 defoliations) or the stocking rate, as in many studies, is inadequate to assess the grazing system. The relationship established between stocking rate on one hand, herbage nitrogen index and herbage volume per animal unit on the other hand, can be used to assess the effect of low grazing pressure on the net stocking rate. It appears that a decrease in the herbage volume from 600 to $300 \mathrm{~m}^{3}$ per AU gives the same increase in the stocking rate as an increase of 15 points in the herbage nitrogen index (Fig. 4). In this way, the herbage volume per animal unit provide useful information to discuss on the flexibility of the grazing management. This allows a diagnosis of the grazing management, i.e., to assess the appropriateness of the stocking rate in relation to the nitrogen supply and the grazing area.

\section{Literature Cited}

Bywater, A.C. and O.J. Cacho. 1994. Use of simulation models in research and teaching. The proc. of the New Zealand society of animal production. 4th conference, Massey Univ., 403-412.

Bélanger, G., F. Gastal and G. Lemaire. 1992. Growth analysis of a tall fescue sward fertilized with different rates of nitrogen. Crop Sci. 32:1371-1376.

Bircham, J.S. 1981. Herbage growth and utilisation under continuous stocking management. Ph.D. Thesis, Univ. of Edinburgh.

Bossuet, L. and M. Duru. 1994. Choix et maîtrise du systèine fourrager. II - Gestion du pâturage tournant en élevage laitier. Fourrages 137:25-42.

Cacho, 0. J., A.C. Finlayson and A.C. Bywater. 1995. A simulation model of grazing sheep :11Whole farm level. Agr. Syst. 48:27-50.

Davies, A. 1988. The regrowth of grass swards. In: the Grass Crop Ed. M.B. Jones and A. Lazenby, 85-117.

Duru, M. and H. Ducrocq. 1998. La hauteur du couvert prairial : un moyen d'estination de Ia quantité d'herbe disponible. Fourrages 154:173-190.

Duru, M., H. Ducrocq, and V. TinIly. 1995. Modeling growth of cocksfoot (Dactylis glomerata L.) and tall fescue (Festuca arun dinacea schreb.) at the end of spring in relation to herbage nitrogen status. J. of Plant Nutrition 18:2033-2047.

Duru, M., J.L. Fiorelli, and P.L. Osty. 1988. Proposition pour le choix et la maîtrise du système fourrager. I Notion de trésorerie fourragère. Fourrages 113:37-56.

Duru, M., G. Lemaire, and P. Cruz. 1997. The nitrogen requirements of grasslands In: Diagnosis of the Nitrogen Status in Crops. G Lemaire ed, Springer Verlag.

Duru, M., E. Justes, A. Langlet, and V. Tirilly. 1993. Coinparaison des dynamiques d'apparition et de mortalité des organes de fétuque élevée, dactyle et luzerne (feuilles, talles et tiges). Agrononie 13:237-252.

Gastal, F., G. Bélanger, and G. Lemaire. 1992. A model of leaf extension rate of tall fescue in response to nitrogen and temperature. Ann. Bot. 70:437-442.

Hoden, A., D. Micol, G. Lienard, A. Muller, and J.L. Peyraud. 1986. "Interprétation des essais depâturage avec des bovins: terminologie, modes de calcul, bilans annuels", Bull. Tech. C.R.Z.V., Theix I.N.R.A. 63:3-42.

Hodgson, J. 1985. The significance of sward characteristics in the management of temperate sown pastures. Proc. XVth Intern. Grassl. Cong., Kyoto 24-31 Aug. 63-67.

Jarrige, R. 1978. Introduction. In: Alimentation des ruminants. Ed. NRA, pp. 621.

Le Du, Y.L.P., R.D. Baker, and R.D. Newberry. 1981. Herbage intake and milk production by grazing dairy cows. 3- Effects of grazing severity under continuous stocking. Grass and Forage Sci. 36:307-318.
Le Du, Y.L.P., J. Combellas, J. Hodgson, and R.D. Baker. 1979. Herbage intake and milk production by grazing dairy cows. 2 The effects of level of winter feeding and daily herbage allowance. Grass and Forage Sci. 34 249-260.

Lemaire, G. and F. Gastal. 1997. N uptake and distribution in plant canopies. In: Diagnosis of the Nitrogen Status in Crops. G Lemaire ed, Springer Verlag.

Lemaire, G. and J. Salette. 1984. Relation entre dynainique de croissance et dynamique de prélèvment dazote pour un peuplement de graininées fourragères. I - Etude de leffet du milieu. Agronoinie 4:423-430.

Maxwell, T.J., A.R. Sibbald, A.J.I. Dalziel, D.D.M. Agnew and D.A. Iston. 1994. The implications of controlling grazed sward height for the operation and productivity of upland sheep systems in UK. 1. Effects of two annual stocking rates in combination with two sward height profiles. Grass and Forage Sci. 49:73-88.

Mayne, O.S., R.D. Newberry, S.C.F. Woodcock, and R.J. Wilkins. 1987. Effect of grazing severity on grass utilization and milk production of rotationally grazed dairy cows. Grass and Forage Sci. 42:59-72.

Mazzanti, A., G. Lemaire, and F. Gastal. 1994. The effect of nitrogen fertilization upon the herbage production of tall fescue swards continuously grazed with sheep. 1 . Herbage growth dynamics. Grass and Forage Sci. 49:111-120.

Parsons, A.J. 1988. The effect of season and management on the growth of grass swards. In: Ed Jones M. B., Lazenby A. The Grass Crop. 129-178.

Parsons, A.J., I.R. Johnson, and A. Harvey. 1988. Use of a model to optimize the interaction between frequency and severity of intermittent defoliation and to provide a fundamental comparison of the continuous and intermittent defoliation of grass. Grass and Forage Sci. 43:49-60.

Peel, S., E.A. Matkin, and C.A. Huckle. 1988. Herbage growth and utilized output from grassland on dairy farms in southwest England: case studies of five farms, 1982 and 1983. II Herbage utilization. Grass and Forage Sci. 43:71-78.

Pflimlin, A. 1995. Europe laitière: diversité, spécificités et complémentarités. Fourrages 143: 5-20

Scarnecchia, D.L. 1988. Grazing, stocking and production efficiencies in grazing research. J. Range Manage. 41:279-281.

Scarnecchia, D.L. 1994. A viewpoint: using multiple variables as indicators in grazing research and management. J. Range. Manage, 47:107-111.

Wilkins, R.J. 1995. Optimisation of grass utilisation in high rainfall temperate conditions. In: Journet M., Grenet E., Farce M.H., Th6riez M., Demarquilly C. (eds). Recent developments in the nutrition of herbivores. Proc. of the lvth Int. Symp. on the nutrition of herbivores, 363-380. NRA Editions, Paris. 